\title{
Histological Characteristics of Gills and Dorsal Skin in Ambystoma leorae and Ambystoma rivulare: Morphological Changes for Living at High Altitude
}

\author{
Características Histológicas de la Piel del Dorso y las Branquias en Ambystoma leorae \\ y Ambystoma rivulare: Cambios Morfológicos para Vivir a Gran Altitud
}

\author{
Jorge Arredondoㅜ; Juan C. González-Morales ${ }^{1}$; Jorge Rodríguez-Antolín²; Elizabeth Bastiaans ${ }^{3}$;
} Octavio Monroy-Vilchis ${ }^{4}$; Javier Manjarrez ${ }^{5}$ \& Victor Fajardo ${ }^{1}$

\begin{abstract}
ARREDONDO, J.; GONZÁLEZ-MORALES, J. C.; RODRÍGUEZ-ANTOLÍN, J.; BASTIAANS, E.; MONROY-VILCHIS, O.; MANJARREZ, J. \& FAJARDO, V. Histological characteristics of gills and dorsal skin in Ambystoma leorae and Ambystoma rivulare: morphological changes for living at high altitude. Int. J. Morphol., 35(4):1590-1596, 2017.

SUMMARY: Vertebrates exhibit structural changes in their cardiovascular and gas exchange systems in response to hypoxic conditions in high altitude environments. In highland neotenic mole salamanders, as other amphibians, the majority of gases exchange is carried out for skin and gills. But, in high altitude environments, the available oxygen is lower than it is in the air thus, the scarcity of oxygen limits the survival of organisms. Many studies on this subject have focused on understanding the hematological mechanisms that amphibians exhibit in response to hypoxia. However, little is known about possible morphological changes in respiratory structures that may permit increased gas exchange during respiration in high altitude amphibians like Ambystoma leorae and A. rivulare, two threatened Mexican salamander species. The aim of the present study was to describe and compare the histological characteristics of the gills and dorsal skin of A. leorae and A. rivulare from populations at low and high altitudes. We found that, in comparison to lowland organisms, highland ones exhibited more pronounced skin folds, greater numbers of secondary branches in the gills, thinner dorsal and gill epidermises, and greater quantity of melanin surrounding the gill blood vessels. These differences permit a greater capacity for gas exchange and also increase thermoregulatory capacity in high altitude environments.
\end{abstract}

KEY WORDS: High altitude; Histology; Critical endangered; Ambystoma rivulare; Ambystoma leorae.

\section{INTRODUCTION}

The neotenic amphibians are species that present a phyletically truncated development with absence of a complete metamorphosis, as well known in Ambystomatidae family (Reilly \& Brandon, 1994), this species of ambystomatidae like mole salamanders retaining larval characteristics, what has been described as an adaptation to aquatic life (Reilly \& Brandon). Ambystoma leorae and A. rivulare are micro-endemic neotenic mole salamander species, strictly restricted to high-altitude mountain streams from central Mexico (Taylor, 1943; Sunny et al., 2014b). Highland aquatic vertebrates are constantly challenged by hypoxia, and most of these vertebrates exhibit related functional and structural modifications. Some of these modifications include: heart size, hemoglobin concentration, capillary density, erythrocyte size and changes in respiratory surfaces (Bouverot, 1985; Ruiz et al., 1989; Monge \& León-Velarde, 1991; Weber, 1995; Samaja et al., 2003; Nikinmaa, 2013).

Most of the studies on high-altitude amphibians are focused on hematological and metabolic changes in response to hypoxia (Ruiz et al., 1983, 1989). For example,

\footnotetext{
${ }^{1}$ Facultad de Medicina Veterinaria y Zootecnia. Universidad Autónoma del Estado de México, México

${ }^{2}$ Centro Tlaxcala de Biología de la Conducta. Universidad Autónoma de Tlaxcala, Km 1.5 Carretera Federal Tlaxcala-Puebla, Tlaxcala, México.

${ }^{3}$ State University of New York, Oneonta. 108 Ravine Parkway, Oneonta, NY 13820, New York.

${ }^{4}$ Centro de Investigacion en Ciencias Biológicas Aplicadas. Universidad Autónoma del Estado de México, Instituto Literario No. 100, Col. Centro, Toluca, Estado de México, México.

${ }^{5}$ Centro de Investigación en Recursos Bióticos, Facultad de Ciencias, Universidad Autónoma del Estado de México. Instituto Literario No. 100, Col. Centro, Toluca, Estado de México, México.
} 
ARREDONDO, J.; GONZÁLEZ-MORALES, J. C.; RODRÍGUEZ-ANTOLÍN, J.; BASTIAANS, E.; MONROY-VILCHIS, O.; MANJARREZ, J. \& FAJARDO, V. Histological characteristics of gills and dorsal skin in Ambystoma leorae and Ambystoma rivulare: morphological changes for living at high altitude. Int. J. Morphol., 35(4):1590-1596, 2017.

some species of highland toads exhibit higher erythrocyte counts, hematocrit, and hemoglobin concentrations compared with lowland toads (Ruiz et al., 1983, 1989). Other studies found lower metabolism in highland toads compared to lowland ones (Hou \& Huang, 1999).

A few studies suggest morphological changes in respiratory surfaces may also occur in response to hypoxia in amphibians. For example, Hutchinson et al.(1976) and Hutchinson (1982) showed an increase of skin surface and dermal capillary density in Telmatobius toads in Lake Titicaca at 3812 meters above sea level, (m asl). Burggren \& Mwalukoma (1983) showed that larval frogs exposed to hypoxia developed thinner skin with more capillary density and a enlargement of gills. Particularly in amphibians the skin and gills are the most important routes for gas exchange (Feder \& Burggren, 1985).

A. leorae and $A$. rivulare are found only above $2800 \mathrm{~m}$ asl (Shaffer et al., 2008a,b; Sunny et al., 2014a,b). The Ambystomatide species endemic to Mexico are members of the Ambystoma tigrinum complex. Phylogenetic studies (Shaffer \& McKnight, 1996; Recuero et al., 2010) suggest that the forms restricted to the Mexican Transvolcanic Belt, diverged very recently (Parra-Olea et al., 2012).

Morphological studies of these respiratory surfaces in this species are important in order to inform management decisions and to preserve both species because the respiratory needs of both species can be very specific. This information is particularly crucial because the high altitude and low temperature habitats of these species represent a hypoxic environment than can produce important unknown morphological modifications. The aim of the present study is to describe the histological characteristics of the gills and skin of A. leorae and A. rivulare.

\section{MATERIAL AND METHOD}

Ethics statement. All experimental procedures were approved by the Ethics Committee of the Universidad Autónoma de Tlaxcala and performed according to the guidelines for the treatment of research animals of the Instituto de Investigaciones Biomédicas, Universidad Nacional Autónoma de México, as well as the Mexican Federal Regulation for Animal Experimentation and Care (NOM-062-ZOO-2001).

Field sites and animals. After governmental approval (SGPA/DGVS/02407/13), due to its conservation status, we collected five mole salamanders of the species A. leorae from Sierra de Rio Frío, the populations of this animals is relatively abundant in the studied population (around of 55 individuals per km (Sunny et al., 2014a,b) $\left(19^{\circ} 20^{\prime} \mathrm{N}\right.$, $98^{\circ} 40^{\prime} \mathrm{W}, 3600 \mathrm{~m}$ asl); and ten mole salamanders of the species A. rivulare, five from Ejido de Loma Alta $\left(19^{\circ} 09^{\prime} \mathrm{N}\right.$, $99^{\circ} 48^{\prime} \mathrm{W}, 3200 \mathrm{~m}$ asl), and five from Amanalco de Becerra $\left(19^{\circ} 18^{\prime} \mathrm{N}, 99^{\circ} 54^{\prime} \mathrm{W}, 2800 \mathrm{~m}\right.$ asl). Animals were captured by hand. Altitude was recorded at the capture site (GPS Etrex Vista, Garmin).

Animals were euthanized with neutral benzocaine 250-mg/L water. Under a surgical microscope (magnification X16, Nikon, model SMZ-2T), and due to the terminal morphology of this specie retains all characteristics of the head and hyobranchial apparatus typical of larvae (Reilly \& Brandon), $1 \mathrm{~cm}^{2}$ of dorsal head skin and all gills were removed. Both tissues were placed in a solution of $70 \%$ alcohol.

Histology. The tissues were washed in water, dehydrated in a series of graded alcohols (70 \%,80\%,96\% and $100 \%)$, cleared in xylene, and embedded in paraplast Xtra (Sakura Finetek, Torrance, CA, USA), cut in 7-mm sections in a microtome (Leica, model CM1850), and the sections were mounted on gelatinized slides.

We used hematoxilin-eosin and Masson's trichrome stain techniques following Humason (1979). For each animal, we obtained 20 transverse serial sections of the central region of the head dorsal skin and 20 more from the right gills. For each tissue type, 10 sections were stained with hematoxylin-eosin and 10 with Masson's trichrome.

Furthermore, for each animal, we obtained 20 sequential sagittal sections from the left gills. Ten were stained with hematoxylin-eosin and 10 with Masson's trichrome.

Histological analysis was performed by means of a microscope (mod. BX41TF: Olympus Corporation, Tokyo Japan) and reviewed with the program SigmaScan Pro version 4 for Windows. The thickness of the dorsal and gill epidermises, the area of the gills, and the area of the blood vessels inside the gills were measured.

Statistical analysis. The data were not normally distributed, so we used a Kruskal-Wallis test to compare gill area, blood vessel area, and the thickness of the gill and dorsal epidermises between the three altitudes from which we sampled salamanders. We also performed a Dunn's posthoc test (SigmaPlot software, version 11 for Windows, USA). All tests were two-tailed, and $\mathrm{P}<0.05$ was taken as the threshold for significance. 


\section{RESULTS}

Dorsal Skin characteristics. Dorsal skin was characterized by the presence of folds, which are most pronounced in individuals from high altitudes, moderately pronounced in individuals from medium altitude, and least pronounced in individuals from low altitude (Fig. $1 \mathrm{~A}, \mathrm{~B}$ and C). Due to this observation, we measured skin surface (thickness and surface between folds) in each section, see next section.

Dorsal skin consists of two layers. The outer layer, or epidermis, is formed by a stratified epithelium consisting of several layers of nonkeratinized squamous cells and basal cells. It also contains unicellular glands that rest on a basal membrane (Fig. 1D).
In all individuals, under the basal membrane we observed a layer of melanocyte-type chromatophores, which are irregular form stellate cells that provide pigment to the skin. Below this layer is the dermis, which consists of conjunctive tissue in which blood vessels and nucleated blood cells can be found (Fig. 1E).

Thickness of the dorsal epidermis. The thickness of the dorsal epidermis differed significantly among individuals from different altitudes. The dorsal epidermis was thicker in individuals from low altitude than in individuals from medium or high altitude $(\mathrm{H}(2)=920.518, \mathrm{p}<0.001$; Fig. 4A). In addition, we measured the skin surface for every section analyzed, and we found significant differences among samples from different altitudes. Individuals from low altitude had lower skin surface area than individuals from medium or high altitudes $(\mathrm{H}(2)=38.009, \mathrm{p}<0.001$; Fig. 4C).
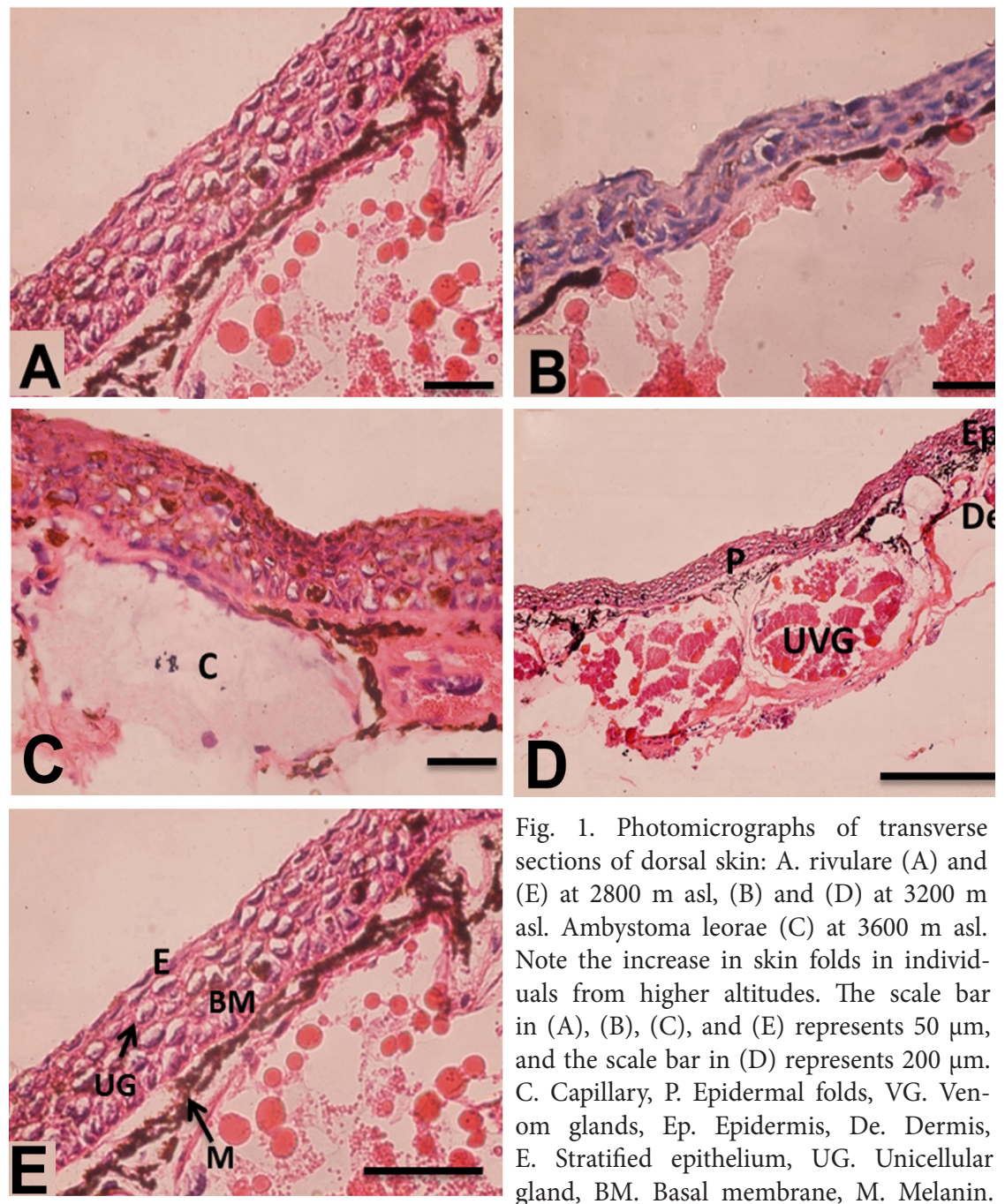

Fig. 1. Photomicrographs of transverse sections of dorsal skin: A. rivulare (A) and (E) at $2800 \mathrm{~m}$ asl, (B) and (D) at $3200 \mathrm{~m}$ asl. Ambystoma leorae (C) at $3600 \mathrm{~m}$ asl. Note the increase in skin folds in individuals from higher altitudes. The scale bar in (A), (B), (C), and (E) represents $50 \mu \mathrm{m}$, and the scale bar in (D) represents $200 \mu \mathrm{m}$. C. Capillary, P. Epidermal folds, VG. Venom glands, Ep. Epidermis, De. Dermis, E. Stratified epithelium, UG. Unicellula gland, BM. Basal membrane, M. Melanin.
Gills characteristics. Gills are organized as a pair of principal gills with secondary lamellae. We observed that the quantity of secondary lamellae increases with increasing altitude. However, the area of the gills decreased with increasing altitude (Fig. 2A, B, and C).

Gills consist of stratified epithelium with squamous cells that are found over a basal membrane. Below the membrane, we observed a layer of melanocyte-type chromatophores. Together with this layer, we observed conjunctive tissue, in which blood vessels containing nucleated blood cells could be found (Fig. 2D).

Around the blood cells, there is a layer of melanocyte-type chromatophores, which is more evident in individuals from greater altitudes. In the gills of individuals from low altitude, the layer of melanocyte-type chromatophores is almost imperceptible in comparison with gills of individuals from medium and high altitudes (Fig. 3A, B, and C).

Thickness of the gill epidermis. differed significantly among individuals from different altitudes. Individuals from low altitude had thicker gill epidermis, compared with those observed in individuals from high or medium altitudes $(\mathrm{H}(2)=111.316, \mathrm{p}<0.001$; Fig. 4B) 

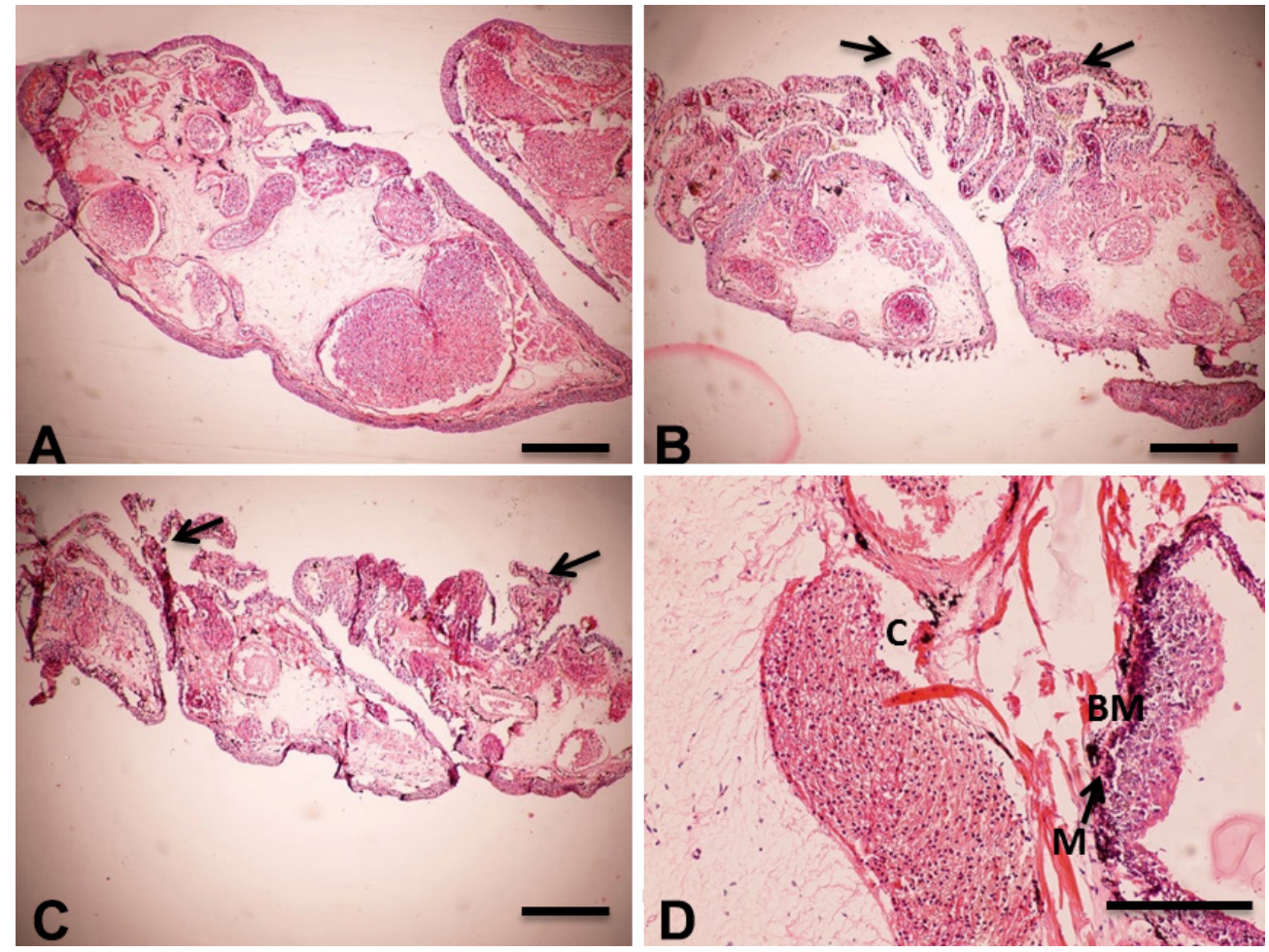

Fig. 2. A, B, and C photomicrographs of transverse sections of gills. Note the increase in the number of secondary branches: A. A. rivulare at $2800 \mathrm{~m}$ asl. B. A. rivulare at 3200 $\mathrm{m}$ asl, and C. A. leorae at $3600 \mathrm{~m}$ asl. D Photomicrograph of a sagittal gill section. The scale bar in $\mathrm{A}, \mathrm{B}$, and $\mathrm{C}$ represents $500 \mu \mathrm{m}$, and the scale bar in D represents $200 \mu \mathrm{m}$. BM. Basal membrane, C. Capillary, M. Melanin.

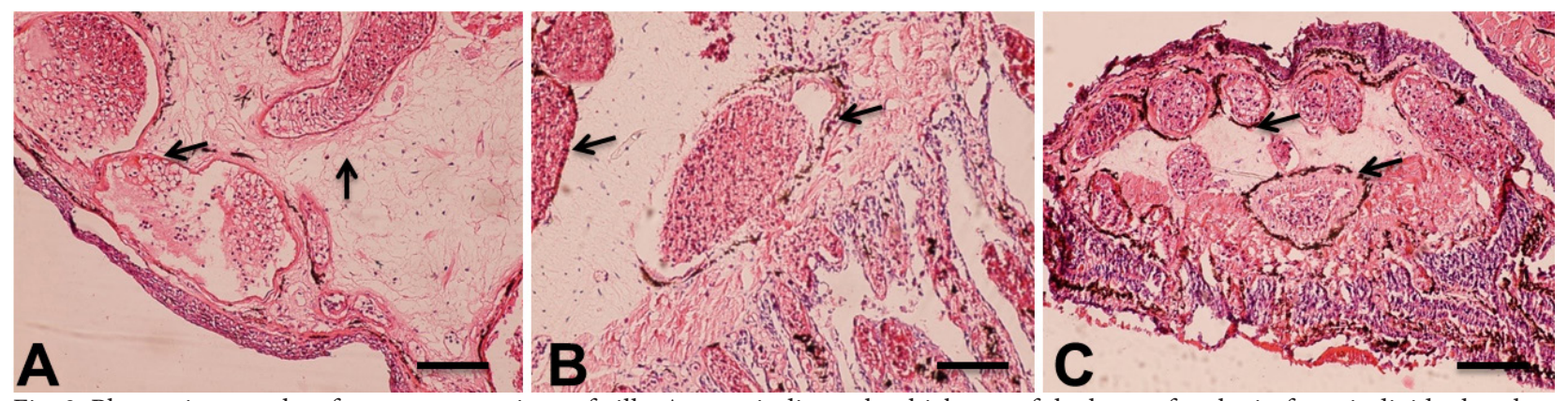

Fig. 3. Photomicrographs of transverse sections of gills. Arrows indicate the thickness of the layer of melanin from individuals collected at three altitudes. (A). A. rivulare at $2800 \mathrm{~m}$ asl. (B). A. rivulare at $3200 \mathrm{~m}$ asl, and (C). A. leorae at $3600 \mathrm{~m}$ asl. The scale bar represents $200 \mu \mathrm{m}$.

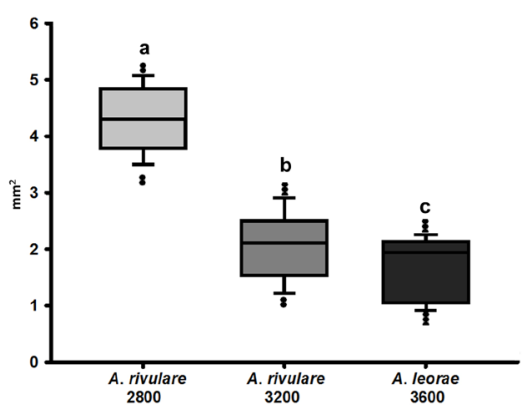

A

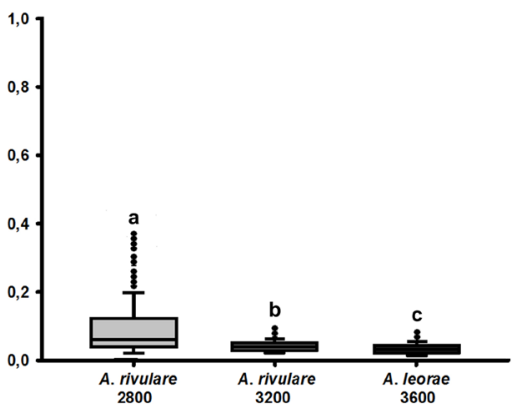

B Mean altitude

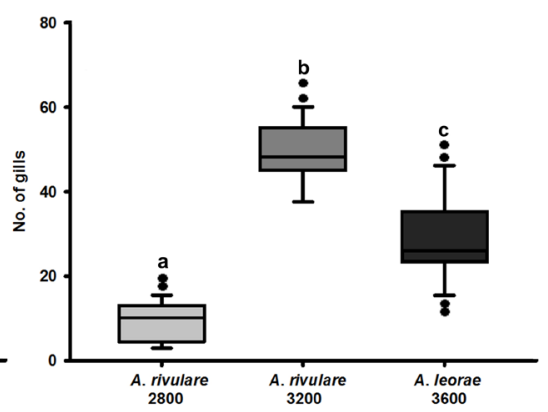

C

Fig. 4. A. thickness of the dorsal epidermis, B. thickness of the gill epidermis, and C. surface between folds. 
Gill area. The area of the gills differed significantly among individuals from the three altitudes. Individuals from low altitude had greater average gill area than individuals from medium or high altitudes $(\mathrm{H}(2)=80.205$, $\mathrm{p}<0.001$; Fig. 5A).
Gill blood vessel area. The area of the gill blood vessels differed significantly among individuals from the three altitudes. Individuals from low altitude had greater gill blood vessel area, on average, than individuals from medium or high altitudes $(H(2)=132.266, p<0.001$; Fig. 5B $)$.

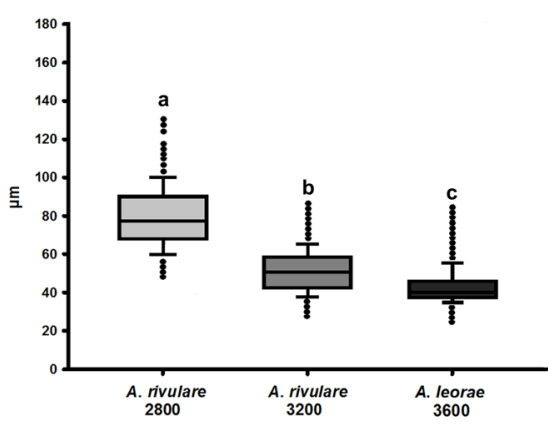

A

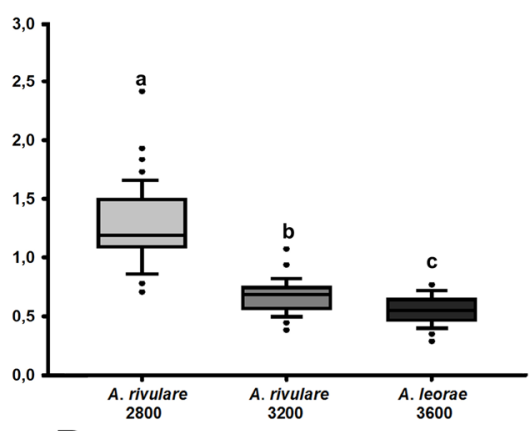

B Mean altitude

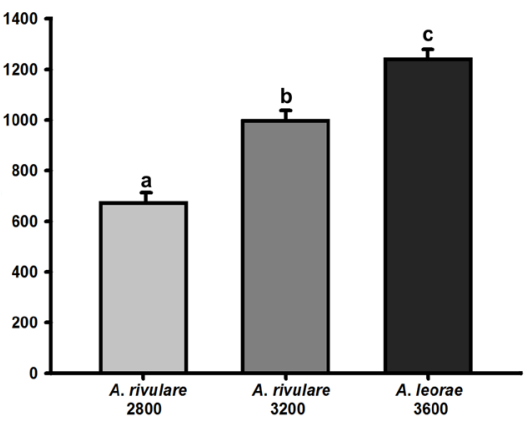

C

Fig. 5. (A) gill area, (B), gill blood vessel area, and (C) number of secondary branches in gills.

\section{DISCUSSION}

In this study, we found that, in comparison with individuals from low altitudes, individuals from high altitudes have more folds in their dorsal skin, thinner dorsal epidermis, a greater number of secondary gill branches, and thinner gill epidermis with smaller blood vessels surrounded by a layer of pigment cells.

The arrangement of the cellular components found in this work is similar to those described by Billett \& Courtenay (1973) and Zug et al. (2001). Skin or integument is composed of an external layer (the epidermis) separated from an internal layer (the dermis) by the basal membrane. The epidermis consists of a stratified epithelium, which contains deep basal cells and superficial apical cells and has a well-vascularized base.

The cellular arrangement of the gills at the epithelial and dermal levels is similar to those described by Hickman et al. (2006) and Zug et al. They found that salamander gills are covered by stratified epithelium, which consists of cells of irregular form and size. Below these lies conjunctive tissue with abundant blood vessels, around which is found a layer of melanocyte-type chromatophores. Trullas et al. (2007) proposed several hypotheses to explain the presence of this layer surrounding the gill blood vessels. The thermal melanism hypothesis is the most accepted and suggests that individuals with greater quantities of melanin thermoregulate more quickly under low temperature conditions. Our results support this hypothesis because as altitude increases (and thus temperature decreases), we found that individuals had more melanin around their gill blood vessels. We suggest a more detailed work on mole salamanders thermorregulation to understand if the malanism hypothesis is supported.

We found that the epidermal thickness of the dorsal skin and the gills decreases with increasing altitude, which may optimize diffusion and gas exchange $\left(\mathrm{O}_{2}\right.$ and $\left.\mathrm{CO}_{2}\right)$ as suggested by Eckert et al. (2002). Based on these results, we can propose that one mechanism to optimize the transference of gases through the skin in hypoxic environments is a reduction in epidermal thickness. Because the availability of $\mathrm{O}_{2}$ is low in these environments, possessing thinner surfaces for gas exchange may facilitate the rate of gas transfer and thus the acquisition of $\mathrm{O}_{2}$.

In studies performed with species of the genus Telmatobius, Hutchison et al. (1976) and Ruiz et al. (1989) observed skin folds, which they stated increased the available surface for gas exchange. Our results show more pronounced skin folds in animals from greater altitudes, which should increase the surface for gas exchange. Along with the decrease in epidermal thickness, this trait may optimize the capture of $\mathrm{O}_{2}$ in hypoxic, high-altitude environments.

We also observed that gill area, as well as the area of gill blood vessels, decrease as altitude increase. This trend may be similar to observations made by Ruiz et al. (1989), who found reduced erythrocyte size to be an adap- 
ARREDONDO, J.; GONZÁLEZ-MORALES, J. C.; RODRÍGUEZ-ANTOLÍN, J.; BASTIAANS, E.; MONROY-VILCHIS, O.; MANJARREZ, J. \& FAJARDO, V. Histological characteristics of gills and dorsal skin in Ambystoma leorae and Ambystoma rivulare: morphological changes for living at high altitude. Int. J. Morphol., 35(4):1590-1596, 2017.

tive factor allowing the aquatic Telmatobius culeus to live at high altitude. Similarly, Novoa et al. (2003), reported a negative correlation between erythrocyte size and altitude in Bufo spinulosus, where individuals distributed along an altitudinal gradient from 3200 to $4300 \mathrm{~m}$ asl. had smaller erythrocytes as altitude increased. In our study, we did not measure erythrocyte size, but we recognize this may be a factor in the reduction of blood vessel area. Unlike mammals, the erythrocytes of ambystomatid salamanders are nucleated (Villalobos et al., 1988), which limits their elasticity or malleability and thus their ability to pass through blood vessels with small diameters. Although a reduction in gill area may represent a substantial disadvantage in hypoxic environments, this disadvantage may be compensated by an increase in the number of secondary gill branches. We found that, as altitude increased, the number of secondary gill branches also increased, generating a greater surface area for gas exchange. This study represents the first observation of this phenomenon.

In summary, ectothermic organisms living at high altitudes overcome the limitations of their environments, such as hypoxia, with structural modifications that allow them to not only exchange gases more easily but also to thermoregulate more efficiently in low temperature environments. Future research would benefit from reciprocal transplant experiments to determine whether these mechanisms represent adaptations or acclimations resulting from phenotypic plasticity.

\section{ACKNOWLEDGMENTS}

We thank the Consejo Nacional de Ciencia y Tecnología (grant 178723) for financial support and the Secretaría de Medio Ambiente y Recursos Naturales for permission to collect animals (SGPA/DGVS/02407/13). We are also thankful to the anonymous reviewers for their valuable comments. To M. Pichardo, I. Velarde and O. Monroy-Vilchis for excellent bibliographical and technical assistance. To the Estacion de Investigación Nevado de Toluca CEPANAF-CICBA for support.

\section{ARREDONDO, J.; GONZÁLEZ-MORALES, J. C.; RODRÍ- GUEZ-ANTOLÍN, J.; BASTIAANS, E.; MONROY-VILCHIS, O.; MANJARREZ, J. \& FAJARDO, V. Características histoló- gicas de la piel del dorso y las branquias en ambystoma leorae y ambystoma rivulare: cambios morfológicos para vivir a gran altitud. Int. J. Morphol., 35(4) :1590-1596, 2017.}

RESUMEN: Los anfibios que viven en ambientes de altitud se enfrentan a factores abióticos que limitan la vida, tales como la disminución de la presión barométrica con la consecuente disminución de la presión parcial de oxígeno $\left(\mathrm{O}_{2}\right)$. Conocer los mecanismos que optimizan la obtención del $\mathrm{O}_{2}$ en estos animales es de gran importancia para entender las diferencias en la sensibilidad a la hipoxia de las diferentes especies. Ambystoma rivulare y A. leorae son anfibios endémicos del Estado de México que viven en ambientes de alta altitud por lo que se cree presentan estrategias fenotípicas para asimilar eficazmente el $\mathrm{O}_{2}$ y poder subsistir en los ambientes de altitud. El objetivo de este trabajo fue analizar las características histológicas de branquias y piel cefálica (que son las principales estructuras que se encargan del intercambio gaseoso) provenientes de tres poblaciones con diferente altitud. Nuestros resultados muestran que los organismos que habitan a mayor altitud tienden a aumentar la superficie de intercambio gaseoso, como es el caso de pliegues epidérmicos y ramas branquiales secundarias. Las diferencias histológicas de branquias y piel cefálica tanto interespecíficas como intraespecíficas respecto a la altitud parecen apoyar la idea de que los organismos modifican sus estructuras para contrarrestar las limitantes de la vida en ambientes de altitud.

PALABRAS CLAVE: Gran altitud; Histologia; Critical endangered; Ambystoma rivulare; Ambystoma leorae.

\section{REFERENCES}

Billett, F. \& Courtenay, T. An estereoscan study of the origin of ciliated cells in the embrionic epidermis of Ambystoma mexicanum. J.Embryol. Exp. Morphol. 29:549-58, 1973.

Bouverot, P. Adaptation to Altitude-Hypoxia in Vertebrates. Berlin, Springer-Verlag, 1985.

Burggren, W. W. \& Mwalukoma, A. Respiration during chronic hypoxia and hyperoxia in larval and adult bullfrogs (Rana catesbeiana). I. Morphological responses of lungs, skin and gills. J.Exp. Biol., 105:191-203, 1983.

Eckert, R.; Randall, D.; Burggren, W. \& French, K. Fisiología Animal: Mecanismos $y$ Adaptaciones. $4^{\text {th }}$ ed. Madrid, McGraw-Hill Interamericana, 2002.

Feder, M. E. \& Burggren, W. W. Cutaneous gas exchange in vertebrates: Design, patterns, control, and implications. Biol.Rev., 60(1):1-45, 1985.

Hickman, C. P.; Roberts, L. S. \& Larson, A. L. Principios Integrales de Zoología. Madrid, McGraw-Hill, 2006.

Hou, P. C. \& Huang, S. P. Metabolic and ventilatory responses to hypoxia in two altitudinal population of the toad, Bufo bankorensis. Comp. Biochem. Physiol. Part A Mol. Integr. Physiol., 124(4):413-21, 1999.

Hutchinson, V. H. Physiological ecology of the telmatobiid frogs of lake Titicaca. Natl. Geog. Soc. Res. Rep., 14:357-61, 1982.

Hutchinson, V. H.; Haines, H. B. \& Engbretson, G. Aquatic life at high altitude: respiratory adaptations in the Lake Titicaca frog, Telmatobius culeus. Respir. Physiol., 27(1):115-29, 1976.

Monge, C. \& León-Velarde, F. Physiological adaptation to high altitude: oxygen transport in mammals and birds. Physiol. Rev., 71(4):1135-72, 1991.

Nikinmaa, M. What is hypoxia?. Acta Physiol., 209(1):1-4, 2013.

Novoa, F. F.; Ruiz, G. \& Rosenmann, M. El Oxígeno y la Vida en Alta Altitud: Adaptaciones en Vertebrados Terrestres. En: Bozinovic, F. (Ed.). Fisiología Ecología y Evolutiva. Santiago de Chile, Ediciones Universidad Católica de Chile, 2003. pp.227-46.

Parra-Olea, G.; Zamudio, K. R.; Recuero, E.; Aguilar-Miguel, X.; Huacuz, D. \& Zambrano, L.. Conservation genetics of threatened Mexican axolotls (Ambystoma). Anim. Conserv., 15(1):61-72, 2012.

Recuero, E.; Cruzado-Cortes, J.; Parra-Olea, G. \& Zamudio, K. R. Urban 
ARREDONDO, J.; GONZÁLEZ-MORALES, J. C.; RODRÍGUEZ-ANTOLÍN, J.; BASTIAANS, E.; MONROY-VILCHIS, O.; MANJARREZ, J. \& FAJARDO, V. Histological characteristics of gills and dorsal skin in Ambystoma leorae and Ambystoma rivulare: morphological changes for living at high altitude. Int. J. Morphol., 35(4):1590-1596, 2017.

aquatic habitats and conservation of highly endangered species: the case of Ambystoma mexicanum (Caudata, Ambystomatidae). Ann. Zool. Fenn., 47(4):223-38, 2010.

Reilly, S. M. \& Brandon, R. A. Partial paedomorphosis in the mexican stream ambystomatids and the taxonomic status of the genus Rhyacosiredon dunn. Copeia, 1994(3):656-62, 1994.

Ruiz, G.; Rosenmann, M. \& Veloso, A. Altitudinal distribution and blood values in the toad, Bufo spinulosus Wiegmann. Comp Biochem Physiol A Comp Physiol., 94(4):643-6, 1989.

Ruiz, G.; Rosenmann, M. \& Veloso, A. Respiratory and hematological adaptations to high altitude in Telmatobius frogs from the Chilean Andes. Comp. Biochem. Physiol. A, 76:109-14, 1983.

Samaja, M.; Crespi, T.; Guazzi, M. \& Vandegriff, K. D. Oxygen transport in blood at high altitude: role of the hemoglobin-oxygen affinity and impact of the phenomena related to hemoglobin allosterism and red cell function. Eur. J. Appl. Physiol., 90(3-4):351-9, 2003.

Shaffer, B.; Huacaz, D.; Flores-Villela, O.; Parra-Olea, G.; Wake, D. \& Papenfuss, T. Ambystoma rivulare. The IUCN Red List of Threatened Species 2008:e.T59067A11865910, 2008b.

Shaffer, H. B. \& McKnight, M. L. The polytypic species revisited: genetic differentiation and molecular phylogenetics of the tiger salamander Ambystoma tigrinum (Amphibia: caudata) complex. Evolution, 50(1):417-33, 1996

Shaffer, H. B.; Parra-Olea, G. \& Wake, D. Ambystoma leorae. The IUCN Red List of Threatened Species 2008:e.T59061A11877775, 2008a.

Sunny, A.; Monroy-Vilchis, O.; Fajardo, V. \& Aguilera-Reyes, U. Genetic diversity and structure of an endemic and critically endangered stream river salamander (Caudata: Ambystoma leorae) in Mexico. Conserv. Genet., 15(1):49-59, 2014a.

Sunny, A.; Monroy-Vilchis, O.; Reyna-Valencia, C. \& Zarco-González, M. M. Microhabitat types promote the genetic structure of a micro-endemic and critically endangered mole salamander (Ambystoma leorae) of Central Mexico. PLoS One, 9(7):e103595, 2014b.

Taylor, E. H. Herpetological novelties from Mexico. Univ. Kans. Sci. Bull., 29(8):343-358, 1943

Trullas, S. C.; van Wyk, J. H. \& Spotila, J. R. Thermal melanism in ectotherms. J. Therm. Biol., 32(5):235-45, 2007.

Villalobos, M.; Léon, P.; Sessions, S. K. \& Kezer, J. Enucleated erythrocytes in plethodontid salamanders. Herpetologica, 44(2):243-50, 1988.

Weber, R. E. Hemoglobin Adaptations to Hypoxia and Altitude: The Phylogenetic Perspective. In: Sutton, J. R.; Houston, C.S. \& Coates, G. (Eds.). Hypoxia and the Brain. Burlington, Queen City Printers, 1995. pp.31-44.

Zug, G. R.; Vitt, L. J. \& Caldwell, J. P. iiSan Diego, Academic Press, 2001.

\section{Corresponding author: \\ Victor Fajardo}

Facultad de Medicina Veterinaria y Zootecnia

Universidad Autónoma del Estado de México

Instituto Literario No. 100, Col. Centro

Toluca, Estado de México

MÉXICO

E-mail: fajardo.vic@gmail.com

Received: 08-03-2017

Accepted: 11-08-2017 